https://www.journal-imab-bg.org

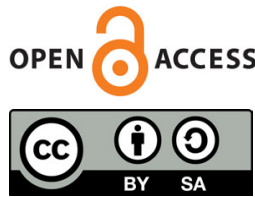

Original article

\title{
LONG TERM FUNCTIONAL STABILITY OF CE- RAMIC VENEERS
}

\author{
Stefka Kazakova, Dimitar Kirov, \\ Department of Prosthetic Dentistry, Faculty of Dental Medicine, Medical Uni- \\ versity, Sofia, Bulgaria.
}

\section{SUMMARY:}

Aim of the study: The aim of the study is long term evaluation according to ADA standard criteria of ceramic adhesively bonded veneers.

Material and Methods: One hundred fifty two patients with 283 ceramic veneers were involved in our study. They were divided into two experimental groups and one control group. The pre-treatment of enamel surface of the first experimental group was with $37 \%$ phosphoric acid. In the second experimental group, the pre-treatment was provided with laser ablation. The pre-treatment in the control group involved three step adhesive system.

Results: After a period of nine years, modified USPHS criteria of the ADA were used to assess the quality of the veneers. We observed one cohesive fracture in ceramics, six marginal discolorations and one loss of marginal adaptation in the first experimental group. We found two marginal discolorations in the second experimental group, one loss of marginal adaptation and one marginal discoloration in the control group.

Conclusion: Laser ablation is a minimally invasive method which provides retentive enamel surface and ensures long term functional stability of ceramic veneers.

Keywords: ceramic veneers, clinical criteria, laser ablation, long term evaluation.

\section{INTRODUCTION}

The minimally invasive ceramic prosthetic restorations of the anterior teeth (ceramic veneers) represent a conservative alternative to the crowns to improve the aesthetic appearance of the teeth. During the last decades, they have been widely used in aesthetic dentistry [1, 2, 3, 4]. There is a tendency to use metal-free restorations in prosthetic dentistry. Patients' increased aesthetic requirements lead to a serious challenge to clinicians for treatment with aesthetic, biologically tolerable and long-term restorations [5, $6,7,8]$. The opportunity of painless treatment options of contemporary laser systems had increased interest of dentists $[9,10,11]$.

The importance of the problem is determined by the opportunity of performing the minimally invasive and painless treatment option with a high aesthetic effect.

\section{MATERIAL AND METHOD:}

Depending on the clinical procedure and the pretreatment of enamel surface, the patients were divided into two experimental and one control groups.

1. The first experimental group included 49 patients $(32 \%)$ in which the enamel surface was treated with $37 \%$ phosphoric acid, and the veneers were cemented with selfetching adhesive cement - MaxCem Elite (Kerr Corporation, Orange, USA).

2 . In the second experimental group, 52 patients (34\%) were involved. The enamel surface was treated with the Waterlase MD Er, Cr: YSGG laser system (Biolase Technology Inc., San Clemente, CA, USA) operating mode: 30 $\mathrm{Hz}, 1 \mathrm{~W}, 10 \%$ water/ $15 \%$ air (10). The laser energy was delivered through a fiber optic system to a sapphire tip measuring $600 \mu \mathrm{m}$ in diameter and $6 \mathrm{~mm}$ in length and selfetching adhesive cement - MaxCem Elite (Kerr Corporation, Orange, USA).

3 . The remaining 51 patients $(34 \%)$ were a control group. The enamel surface was treated with $37 \%$ phosphoric acid, followed by adhesive and composite cement Variolink Veneer (IvoclarVivadent, Schaan Liechtenstein).

After a period of nine years, modified USPHS (United States Public Health System) criteria of the American Dental Association (ADA) were used to assess the quality of the veneers.

Statistical analyses were performed by one-way ANOVA with a Tukey post hoc test. The statistical analysis of the results obtained was conducted using a significance level of $5 \%(\mathrm{p} \leq 0.05)$. Descriptive evaluation methods were applied - absolute and relative frequencies. Statistical data processing was performed using IBM SPSS Statistics 20 (IBM - USA).

\section{RESULTS:}

The distribution of veneers of the patients in studied groups is presented in Table 1 . 
Table 1. Distribution of veneers according to the pre-treatment of the enamel surface for adhesive cementation.

\begin{tabular}{|c|c|c|c|}
\hline Groups Age & $20-30$ age & $31-41$ age & Total $(\%)$ \\
\hline 1 & 37 & 52 & $89(31,45 \%)$ \\
\hline 2 & 46 & 50 & $96(33,92 \%)$ \\
\hline 3 & 47 & 51 & $98(34,63 \%)$ \\
\hline
\end{tabular}

Legend:

1. Pretreatment of the enamel tooth surface with $37 \%$ phosphoric acid and application of self-adhesive composite cement.

2. Pre-treatment of the enamel tooth surface with the following laser ablation mode and application of self-adhesive composite cement.

3. Pretreatment of the enamel tooth surface with $37 \%$ phosphoric acid and application of adhesive and composite cement.

Slight marginal staining was found in six of the ceramic veneers in the first experimental group (Figure 1). In this group, loss of marginal adaptation was observed in one of the veneers.

Fig. 1. Marginal discoloration in mesial margin of upper lateral incisor.

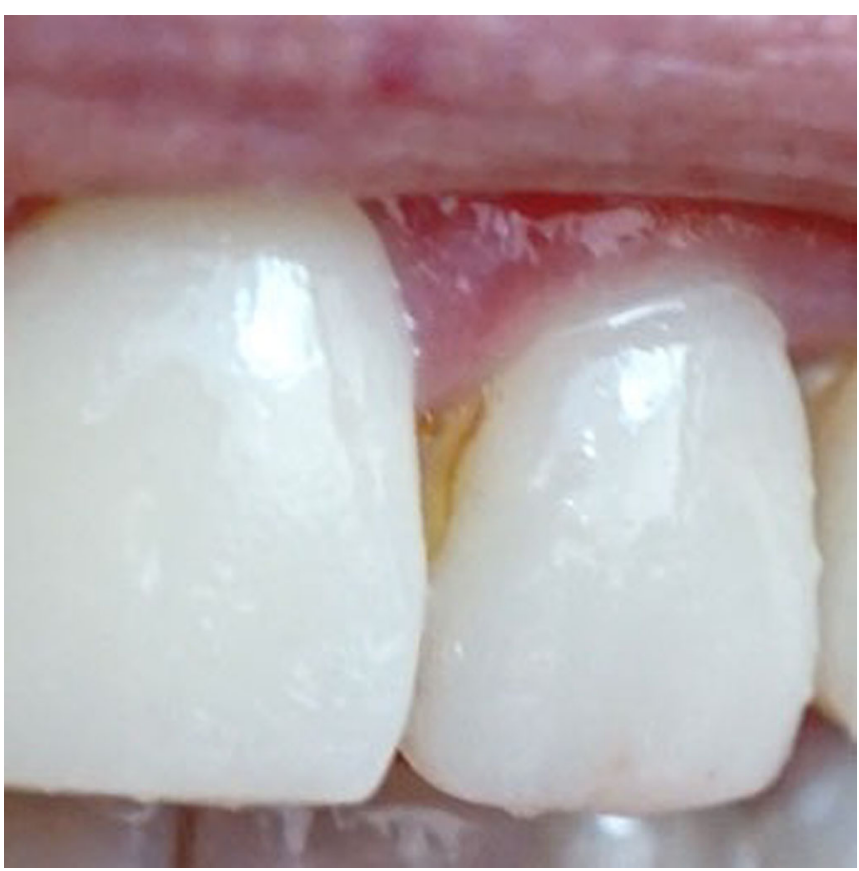

In the clinical evaluation of ceramic veneers in the first experimental group, the main failure was associated with cohesive fracture of ceramic veneer (Figure 2). Pretreatment of the enamel tooth surface in this group included etching with $37 \%$ phosphoric acid and application of Maxcem Elite adhesive cement (Kerr Corporation, Orange, USA).

Fig. 2. Fractured porcelain veneer.

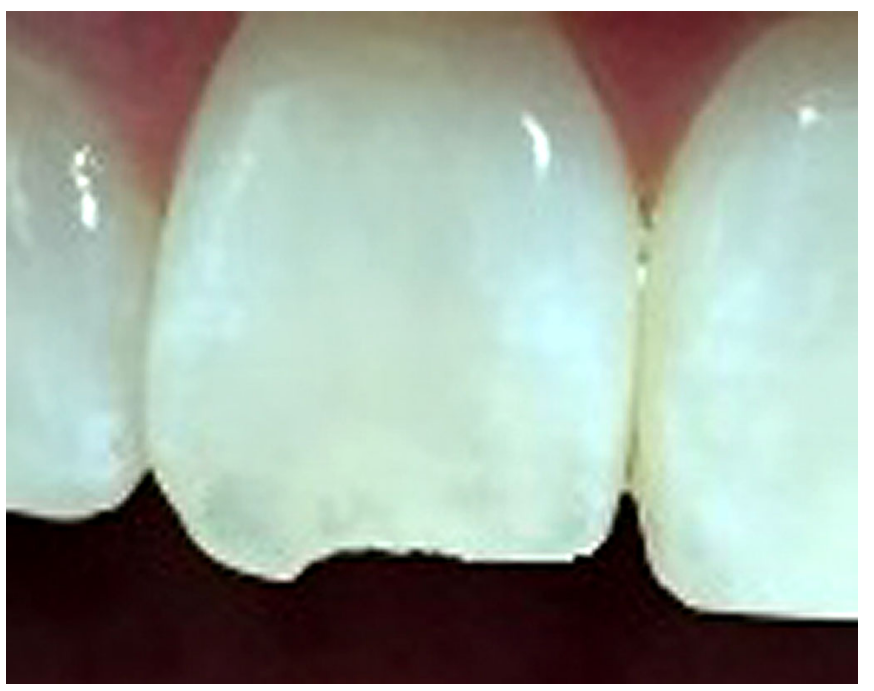

In the second experimental group, we observed two marginal discolorations, one loss of marginal adaptation. One marginal discoloration was found in the control group. We established color matching and patient satisfaction. This study was not detected any secondary caries or need for root canal treatment.

The results of the clinical criteria assessment of the ceramic veneers are presented in Table 2. 
Table 2. Evaluation by standard clinical criteria of minimally invasive adhesively bonded ceramic veneers.

\begin{tabular}{|c|c|c|c|c|}
\hline \multirow{2}{*}{$\begin{array}{l}\text { Clinical } \\
\text { criteria }\end{array}$} & \multirow[b]{2}{*}{ Evaluation } & \multicolumn{3}{|c|}{ Experimental groups } \\
\hline & & 1 group & 2 group & 3 group \\
\hline \multirow{4}{*}{$\begin{array}{c}\text { Marginal } \\
\text { adaptation }\end{array}$} & 1 & $\mathrm{n}=89$ & $\mathrm{n}=96$ & $\mathrm{n}=97$ \\
\hline & 2 & & & \\
\hline & 3 & & & $\mathrm{n}=1$ \\
\hline & 4 & & & \\
\hline \multirow{4}{*}{$\begin{array}{c}\text { Marginal } \\
\text { discoloration }\end{array}$} & 1 & $\mathrm{n}=85$ & $\mathrm{n}=94$ & $\mathrm{n}=97$ \\
\hline & 2 & & & \\
\hline & 3 & $\mathrm{n}=6$ & $\mathrm{n}=2$ & $\mathrm{n}=1$ \\
\hline & 4 & & & \\
\hline \multirow{4}{*}{$\begin{array}{l}\text { Anatomical } \\
\text { form }\end{array}$} & 1 & $\mathrm{n}=88$ & $\mathrm{n}=96$ & $\mathrm{n}=98$ \\
\hline & 2 & & & \\
\hline & 3 & & & \\
\hline & 4 & $\mathrm{n}=1$ & & \\
\hline \multirow{4}{*}{$\begin{array}{l}\text { Surface } \\
\text { roughness }\end{array}$} & 1 & $\mathrm{n}=89$ & $\mathrm{n}=96$ & $\mathrm{n}=98$ \\
\hline & 2 & & & \\
\hline & 3 & & & \\
\hline & 4 & & & \\
\hline \multirow{4}{*}{$\begin{array}{l}\text { Color } \\
\text { match }\end{array}$} & 1 & $\mathrm{n}=89$ & $\mathrm{n}=96$ & $\mathrm{n}=98$ \\
\hline & 2 & & & \\
\hline & 3 & & & \\
\hline & 4 & & & \\
\hline \multirow{4}{*}{$\begin{array}{l}\text { Presence } \\
\text { of caries }\end{array}$} & 1 & $\mathrm{n}=89$ & $\mathrm{n}=96$ & $\mathrm{n}=98$ \\
\hline & 2 & & & \\
\hline & 3 & & & \\
\hline & 4 & & & \\
\hline \multirow{5}{*}{$\begin{array}{c}\text { Fracture } \\
\text { of } \\
\text { restoration }\end{array}$} & 1 & $\mathrm{n}=88$ & $\mathrm{n}=96$ & $\mathrm{n}=98$ \\
\hline & 2 & & & \\
\hline & 3 & $\mathrm{n}=1$ & & \\
\hline & 4 & & & \\
\hline & 5 & & & \\
\hline
\end{tabular}

The p-value corresponding to the F-statistic of one-way ANOVA is lower than 0.05 which strongly suggests that one or more pairs of treatments are significantly different (Table 3 ).

Table 3. Results of the F-statistic of one-way ANOVA

\begin{tabular}{|l|c|c|c|c|c|}
\hline & SS & df & MS & F statistic & p-value \\
\hline Between groups & 0,2928 & 2 & 0,1464 & 3,6599 & 0,0270 \\
\hline Within groups & 11,1984 & 280 & 0,04 & & \\
\hline total & 11,4912 & 282 & & & \\
\hline
\end{tabular}

df- degrees of freedom; SS- sum of squares; MS- mean square; F- F statistic; 
We present below color coded results (red for insignificant, green for significant) of evaluating whether Qi,j>Qcritical for all relevant pairs of treatments (Table 4).

Table 4. Post-hoc Tukey HSD test results.

\begin{tabular}{|c|c|c|c|}
\hline $\begin{array}{c}\text { treatments } \\
\text { pair }\end{array}$ & $\begin{array}{c}\text { Tukey HSD } \\
\text { Q statistic }\end{array}$ & $\begin{array}{c}\text { Tukey HSD } \\
\text { p-value }\end{array}$ & $\begin{array}{c}\text { Tukey HSD } \\
\text { inferfence }\end{array}$ \\
\hline A vs B & 3,3186 & 0,0512351 & insignificant \\
\hline A vs C & 3,3555 & 0,0480004 & insignificant \\
\hline B vs C & 0,0209 & 0,8999947 & int \\
\hline
\end{tabular}

Statistical analysis of the tested experimental groups demonstrated a significant difference only between the first and the third group. There was observed the statistically significant difference between the first experimental group and the control group. The second experimental group has a statistically insignificant difference with the control group.

\section{DISCUSSION:}

In the first experimental group, we observed the highest failure rate. Slightly marginal staining was observed in 6 of the veneers, a possible cause of which was smoking. With finishing diamond burs, it was removed.

The absence of more cases with marginal discoloration is explained by the better color stability of light-polymerizing composite cement.

The result of our research shows that the most common cause of failure is the discoloration of restorations, which is consistent with previous studies [12, 13, 15].

This means that, despite the advantages of materi- als and techniques, there are other factors that determine the long-term functional stability of the restoration. In this study, after five-years of function cohesive fracture affected the veneer of the upper lateral incisor, where the restoration included a minimal incisal overlap. The occlusal factors, according to our study are fundamental to this failure. Dental ceramics are fragile materials with a relatively high compressive strength but with low tensile and bending strengths. Their strength is largely due to the adhesive bonding of the composite cement to enamel surface and to the fluorocarbon-etched ceramic surface.

\section{CONCLUSION:}

Ceramic veneers can successfully and long-term restore aesthetics of the anterior teeth. Laser ablation is a minimally invasive method of pre-treatment of the enamel surface which provides retentive enamel surface and ensures long term functional stability of ceramic veneers. The laser ablation of the enamel can successfully substitute acid etching.

\section{REFERENCES:}

1. Alencar MS, Araújo DF, Maenosono RM, Ishikiriama BL, Francischone CE, Ishikiriama SK. Reestablishment of esthetics with minimum thickness veneers: a one year follow-up case report. Quintessence Int 2014 Jul-Aug;45(7):593-7. [PubMed] [CrossRef]

2. Banerjee S. Porcelain laminate veneers - a panacea for a decrepit smile. Clinical Dentistry 2014 Feb;8(2):21-25.

3. da Cunha LF, Gonzaga CC, Saab R, Mushashe AM, Correr GM. Rehabilitation of the dominance of maxillary central incisors with refractory porcelain veneers requiring minimal tooth preparation. Quintessence Int. 2015 Nov-Dec;46(10):837-41. [PubMed] [CrossRef]

4. Edelhoff D, Liebermann A, Beuer
F, Stimmelmayr M, Güth JF. Minimally invasive treatment options in fixed prosthodontics. Quintessence Int. 2016 Mar;47(3):207-16. [PubMed]

5. Araujo NS, Moda MD, Silva EA, Zavanelli AC, Mazaro JV, Pellizer EP. Survival of all-ceramic restorations after a minimum follow-up of five years: a systematic review. Quintessence Int. 2016; 47(5):395-405. [PubMed] [CrossRef]

6. de Carvalho Cardoso P, de Almeida Decurcio R, Almeida e Silva JS, Perillo MV, Baratieri LN. Noninvasive Porcelain Veneers: A Comprehensive Esthetic Approach. Am J Esthet Dent. 2012 Winter;2(4):238-54.

7. Rinke S, Lange K, Ziebolz D. Retrospective study of extensive heatpressed ceramic veneers after 36 months. J Esthet Restor Dent. 2013
Feb;25(1):42-52. [PubMed] [CrossRef]

8. Cotert HS, Dundar M, Ozturk B. The effect of various preparation designs on the survival of porcelain laminate veneers. Adhes Dent. 2009 Oct;11(5):405-11. [PubMed]

9. Basaran EG, Ayna E, Basaran G, Beydemir K. Influence of different power outputs of erbium, chromium: Yttrium-scandium-gallium-garnet laser and acid etching on shear bond strengths of a dual-cure resin cement to enamel. Lasers Med Sci. 2011 Jan;26(1):13-9. [PubMed]

10. Kamenova J. [Application of diode laser systems in dentistry.] Ivrai. 2014. [In Bulgarian]

11. Hoshing UA, Patil S, Medha A, Bandekar SD. Comparison of shear bond strength of composite resin to enamel surface with laser etching ver- 
sus acid etching: An in vitro evaluation. J Conserv Dent. 2014 Jul;17(4): 320-324.

12. Azer SS, Rosensteil SF, Seghi RR, Johnston, WM. Effect of substrate shades on the colour of ceramic laminate veneers. J Prosthet Dent. 2011 Sep;106(3):179-183. [PubMed]

13. da Cunha LF, Pedroche LO,
Gonzaga CC, Furuse AY. Esthetic, occlusal and periodontic rehabilitation of anterior teeth with minimum thickness porcelain laminate veneers. J Prosthet Dent. 2014 Dec;112(6):1315-8. [PubMed] [CrossRef]

14. Fradeani M. Redemagni M, Corrado M. Porcelain laminate veneer 6-to 12 years clinical evaluation - a retrospective study. Int J Periodontics Restorative Dent. 2005 Feb;25(1):9-17. [PubMed]

15. Parker SP, Darbar AA, Featherstone JD, Iaria G, Kesler G, Rechmann P, et al. The Use of Laser Energy for Therapeutic Ablation of Intraoral Hard Tissues. J Laser Dent. 2007; 15(2):78-86.

Please cite this article as: Kazakova S, Kirov D. Long term functional stability of ceramic veneers. J of IMAB. 2018 Apr-Jun;24(2):2002-2006. DOI: https://doi.org/10.5272/jimab.2018242.2002

Received: 02/03/2018; Published online: 04/06/2018

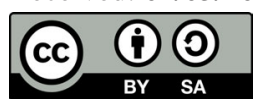

Address for correspondence:

Dimitar Kirov, assistant Professor, DDS, PhD

Department of Prosthetic Dentistry, Faculty of Dental Medicine, Medical University, Sofia,

1, St. Georgi Sofyiski Str., 1431 Sofia, Bulgaria.

Tel.:+35988 8518894

e-mail: dimiterkirov@gmail.com 